\title{
Assessment of the flow of impression material into the gingival sulcus depending on the type of impression material used and the impression-taking technique
}

\author{
Ocena zdolności zapływania masy wyciskowej w rowek dziąsłowy \\ w zależności od zastosowanej masy wyciskowej i techniki pobierania \\ wycisku
}

\author{
Julita Maria Stępień, Beata Dejak \\ Zakład Protetyki Stomatologicznej, Uniwersytet Medyczny w Lodzi \\ Department of Prosthodontics, Medical University in Lodz \\ Kierownik: prof. dr hab. n. med. Beata Dejak
}

KEY WORDS:

impression material, gingival sulcus, impression technique

\section{Summary}

Introduction. Effective preparation of the shoulder margin in abutment teeth for crowns and bridges is the key factor determining the seal and durability of such restorations.

Aim of the study. To assess the flow of impression material into the gingival sulcus, taking into account the impression material used and the impression-taking technique.

Material and methods. Eight impression materials were tested and six impression techniques were examined. The standard for the study was a model of the mandible and prepared teeth 43 and 46. A simulation was made of gingival sulci $200 \mu \mathrm{m}$ in width in the region of the abutment teeth. The study material comprised 250 impressions.

Results. The greatest material flow in the gingival sulcus was achieved with the two-step two-phase technique without cutting-out a layer of impression material in the cervical area. A twostep two-phase method produced a greater flow of impression material into the gingival sulcus
HASŁA INDEKSOWE:

masa wyciskowa, rowek dziąsłowy, technika wyciskowa

Streszczenie

Wprowadzenie. Granica preparacji stopnia w zębach filarowych pod korony $i$ mosty ma decydujace znaczenie dla szczelności i trwałości tych uzupetnień.

Cel pracy. Celem pracy była ocena zdolności zapływania masy wyciskowej $w$ rowek dziastowy $w$ zależności od rodzaju użytej masy wyciskowej $i$ zastosowanej techniki wyciskowej.

Material i metody. Badaniom poddano osiem mas wyciskowych (Aquasil, Honigum, Silagum, Express, Variotime, Impregum, Monophase, Identinum), zbadano sześć technik wyciskowych. Wyciski pobierano na łyżkach standardowych oraz na tyzkach indywidualnych. Wzorcem do badań byt model zuchwy z oszlifowanymi pod most zębami 43 i 46. W okolicy zębów filarowych wykonano imitację rowków dziastowych o szerokości 200 um. Wyciski wzorca pobierano z wykorzystaniem specjalnie skonstruowanego urzadzenia. Materiat badany obejmowat 250 wycisków. Glębokość masy zaptywajacej $w$ rowek dziastowy mierzono za pomoca suwmiarki z funkcja głębokościomie- 
than single-step techniques. Material flow in the gingival sulcus was weaker when impressions were taken with customized trays compared with standard trays.

Conclusions. 1. The deepest flow in the gingival sulcus was achieved with Silagum using a twostep two-phase technique with cut-out interdental spaces. 2. Impression material achieves greater flow in the gingival sulcus when two-step twophase techniques are used than with one-step one-phase techniques. 3. Impression material applied in standard trays ensured deeper flow in the gingival sulcus than impressions taken in custom-made trays. rza. Dla poszczególnych badanych grup obliczono średnie gtębokości zaptywania masy w rowek dziastowy.

Wyniki. Najgłębiej w kieszonke zaptywaty masy w technice dwuczasowej dwuwarstwowej, bez wycinania I warstwy masy w obrębie szyjek zębowych. Gtębiej masa wyciskowa zaptywata w kieszonki w technikach dwuwarstwowych dwuczasowych w porównaniu do technik jednoczasowych. Podczas pobierania wycisków na tyżkach indywidualnych zaobserwowano mniejsza tendencje masy do zaptywania $w$ kieszonke dziasto$w a$, niż w przypadku stosowania tyżek standardowych.

Wnioski. 1. Najgłębiej w kieszonkę dziąstowa zapływa masa Silagum - technika dwuczasowa dwuwarstwowa $z$ wyciętymi przestrzeniami międzyzębowymi. 2. W technikach dwuczasowych dwuwarstwowych masa wyciskowa ma większa zdolność do zaptywania w rowek dziąsłowy niż w technikach jednoczasowych jednowarstwowych. 3. Stosujac tyżki standardowe masa wyciskowa ma tendencje do głębszego zapływania $w$ rowek dziąstowy, w porównaniu do wycisków pobieranych na tyzkach indywidualnych.

Subgingival crowns are recommended only in cases of damage below the gingival line (presence of subgingival fillings, caries), short clinical crowns (to improve retention and stabilization of prosthetic crowns), and significantly discoloured teeth. The grey ring around composite crowns placed in the anterior segment must be concealed subgingivally for aesthetic reasons. When preparing the subgingival zone gingival retraction is essential. $^{5-7}$

The depth of the gingival sulcus in healthy periodontium ranges from 0.5 to $2 \mathrm{~mm}$. On average, it is $1 \mathrm{~mm} .{ }^{8}$ When periodontitis occurs, the pocket increases in size. An accurate simulation of this zone depends, among other things, on the health of the periodontal tissue, the depth of the subgingival preparation of 


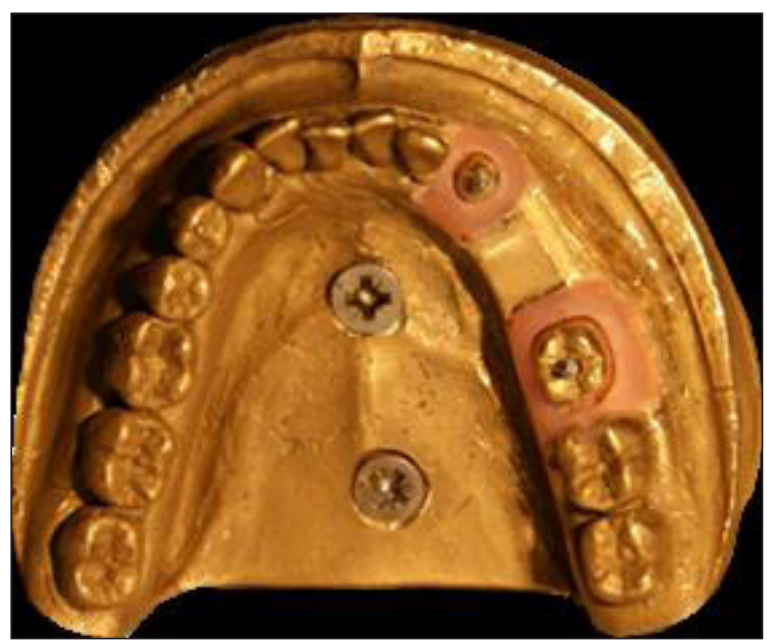

Fig. 1. Model with prepared teeth 43 and 46 gingival sulci formed brass.

the tooth, gum bleeding during impression taking, infiltration of the pocket fluid, and the amount of saliva present. ${ }^{9}$ It is important to note that prosthetic restorations should be made in patients enjoying good periodontal health.

Of key clinical importance is precise modelling of the prosthetic field in the gingival zone. Material that penetrates deeper into the gingival sulcus provides us with more effective gingival retraction and more precise registration of the preparation margin. A key factor in ensuring precise fitting of prosthetic restorations (crowns, bridges, inlays) is precise modelling of the gingival area, including preparation of the shoulder. The marginal seal and clinical durability of prosthetic restorations depends on meticulous fabrication of the prosthetic restoration and precise bonding with the shoulder prepared in the dental tissue. ${ }^{10,11}$

\section{Objective of study}

The objective of this study was to assess the flow of impression material into the gingival sulcus, taking into account the impression material used and the impression-taking technique.

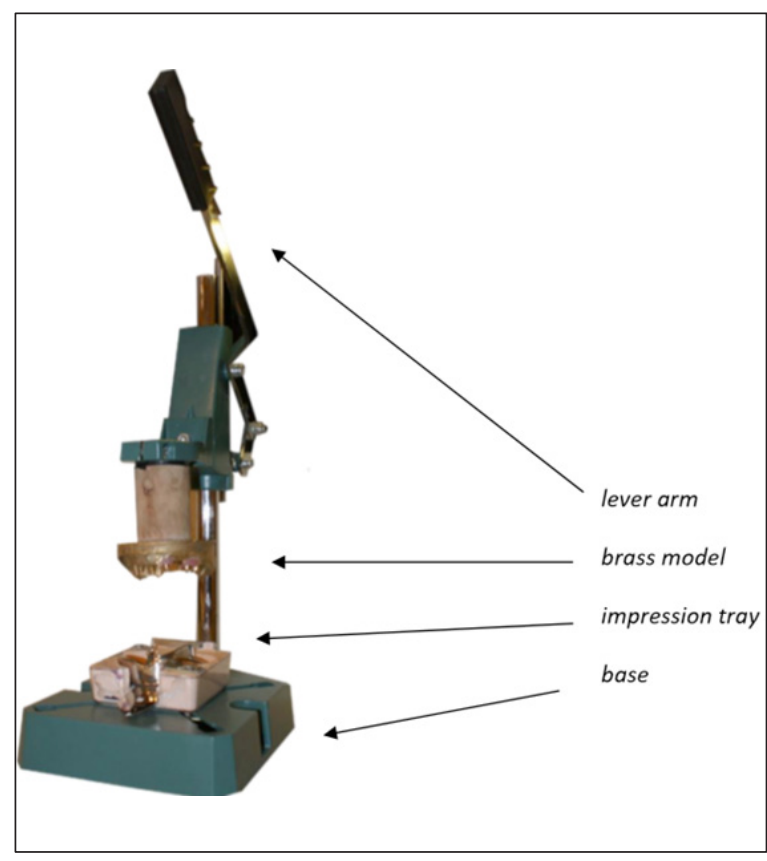

Fig. 2. Impression-taking device.

\section{Study material and methods}

For the purposes of the study a model of the underlying tissue was formed. Teeth 43 and 46 in a model of a full lower arch (KaVo, Biberach, Germany) were prepared for a bridge, in accordance with accepted standards. This model was reproduced in brass and served as a standard for further research. Replicas were made of gingival sulci around the abutment teeth (Fig. 1). To achieve this goal, firstly, some of the material was removed from the gingival area around the abutment teeth to a depth of about $0.5 \mathrm{~cm}$, and then retention elements for the acrylic were fixed in the rest of the brass. The cervical areas of the abutment teeth were covered with 0.2 mm of wax - to imitate the sulci. An acrylic jacket was then made to imitate the soft tissue around the teeth. Following polymerization of the jacket the final acrylic treatment was performed. A small incision was made on the distal aspect of tooth 43, which made it possible to determine the gingival measurement point 
Table 1. Study groups

\begin{tabular}{|c|c|c|c|c|c|c|}
\hline & 1 & 2 & 3 & 4 & 5 & 6 \\
\hline $\begin{array}{l}\text { Aquasil Soft Putty/ } \\
\text { Aquasil Ultra LV }\end{array}$ & 10 & - & 10 & 10 & 10 & 10 \\
\hline $\begin{array}{l}\text { Expres XT Penta H/ } \\
\text { Express XT Light Body }\end{array}$ & 10 & - & 10 & 10 & 10 & - \\
\hline $\begin{array}{l}\text { Honigum-Putty Soft/ } \\
\text { Honigum Light }\end{array}$ & 10 & - & 10 & 10 & 10 & - \\
\hline $\begin{array}{l}\text { Silagum-Putty Soft/ } \\
\text { Silagum Light Fast }\end{array}$ & 10 & - & 10 & 10 & 10 & - \\
\hline $\begin{array}{l}\text { Variotime Heavy Tray/ } \\
\text { Variotime Light Flow }\end{array}$ & 10 & - & 10 & 10 & 10 & - \\
\hline Impregum Penta & - & 10 & - & - & - & 10 \\
\hline Monophase & - & 10 & - & - & - & - \\
\hline $\begin{array}{l}\text { Identium Heavy/ } \\
\text { Identium Light }\end{array}$ & 10 & - & - & - & - & - \\
\hline
\end{tabular}

Legend:

1 - One-step two-phase technique,

2 - One-step, one-phase technique,

3 - Two-phase correction impression technique with interdental spaces removed and gingival section excised,

4 - Two-step two-phase technique using unprepared abutment teeth in the first impression layer,

5 - Two-step two-phase technique with interdental spaces removed,

6 - One-step technique using individual tray.

(depth of impression material flowing into the gingival sulcus), which had a width of $200 \mu \mathrm{m}$.

Eight impression materials were used in the experiment, including five polyvinyl siloxane materials: Aquasil Soft Putty/Aquasil Ultra LV (Densply, Konstanz, Germany), HonigumPutty Soft/Honigum Light (DMG, Hamburg, Germany), Silagum-Putty Soft/Silagum Light (DMG, Hamburg, Germany), Express XT Penta H/Express XT Light Body (3M ESPE, Seefeld, Germany), Variotime/Variotime Light Flow (Heraeus Kulzer, Hanau, Germany); two polyether materials: Impregum Penta (3M ESPE, Seefeld, Germany) and Monophase (3M ESPE, Seefeld, Germany); as well as well as one form of vinyl siloxane ether: Identium Heavy / Identium Light (Kettenbach GmbH\&Co. $\mathrm{KG}$, Eschenburg, Niemcy). The impressions were taken with standard L1 Rim Lock metal impression trays (Falcon, Sialkot, Pakistan) and with light-cured Plaque Photo custom trays (Willmann \& Pein GmbH, Barmstedt, Germany). The trays were covered with Vps tray Adhesive (3M ESPE, Seefeld, Germany) for type A silicones, Polyether Adhesive (3M ESPE, Seefeld, Germany) for polyether and Identium Adhesive (Kettenbach GmbH\&Co. $\mathrm{KG}$, Eschenburg, Germany) and for vinyl siloxane ether.

Standard impressions were taken using a specially constructed device. Initially, the standard model (of the dental arch) was mounted onto the upper lever of the device (Fig. 2). The impression tray together with the material was placed on a base, in a place ensuring its repeatable and clear orientation. Impressions were taken by lowering the lever arm, which resulted in the model of the standard being 


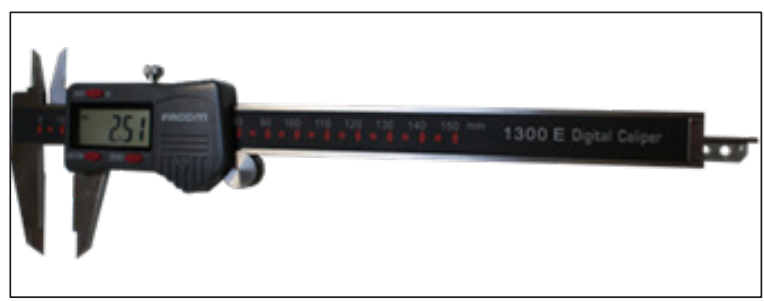

Fig. 3. Calliper with digital readout and depth gauge function.

placed in the impression tray with material. The point limiting the depth of entry of the model into the material was the edge of the impression tray. The model of the standard remained in the impression tray and material for $12 \mathrm{~min}$. It was decided to extend the recommended time set by impression material manufacturers because the polymerization process took place at a room temperature of approximately $22^{\circ} \mathrm{C}$.

The study material comprised 250 impressions - 10 in each study group (Table 1). Each group comprised impressions made with the same impression material and using one of the 6 impression techniques tested and the same type of impression trays. The depth of material penetration into the gingival sulcus was examined and compared in relation to the following impression techniques:

- one-step two-phase technique,

- one-step one-phase technique,

- two-step two-phase technique with interdental spaces and gingival part removed,

- two-step two-phase technique using unprepared abutment teeth in the first impression layer,

- two-step two-phase technique with interdental spaces removed,

- one-step technique using a custom impression tray.

The depth of the material flow into the gingival sulcus during impression taking was measured using a calliper (Facom, Morangis, France) equipped with a digital reading and depth gauge function (Fig. 3). The depth gauge

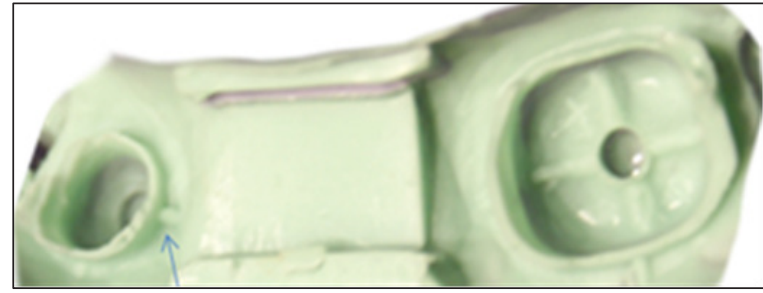

Fig. 4. Impression with the measuring point marked on tooth 43.

tip was applied to the measuring point on the buccal side of tooth 43 (Fig. 4). The depth of the material flow into the gingival sulcus was measured in $\mathrm{mm}$.

\section{Results}

Figure 5 and Table 2 show a comparison of the flow depth of the impression materials in the gingival sulcus with a width of $200 \mu \mathrm{m}$, using various impression techniques ( $\mathrm{mm}$ ).

\section{Materials}

In the case of the one-step, two-phase technique, all the materials flowed to a similar depth, ranging from $1.524 \mathrm{~mm}$ to $1.66 \mathrm{~mm}$.

Material flow in the gingival pocket was weaker when impressions were taken using customized trays and Aquasil and Impregum materials (6) compared with when the same materials were used in combination with standard trays $(1,2$; difference for Aquasil $0.022 \mathrm{~mm}$, for Impregum $-0.224 \mathrm{~mm}$ ). The weakest flow in the gingival sulcus occurred when Impregum was combined with a one-step technique and a custom tray $(6 ; 0.856 \mathrm{~mm})$.

Material flow was greater with two-step two-phase techniques than with one-step methods (groups 2, 6). Material flow in the pocket was at its deepest when the two-step two-phase technique was used and without removing the first layer of the material from the cervical area of the teeth (ranging from 


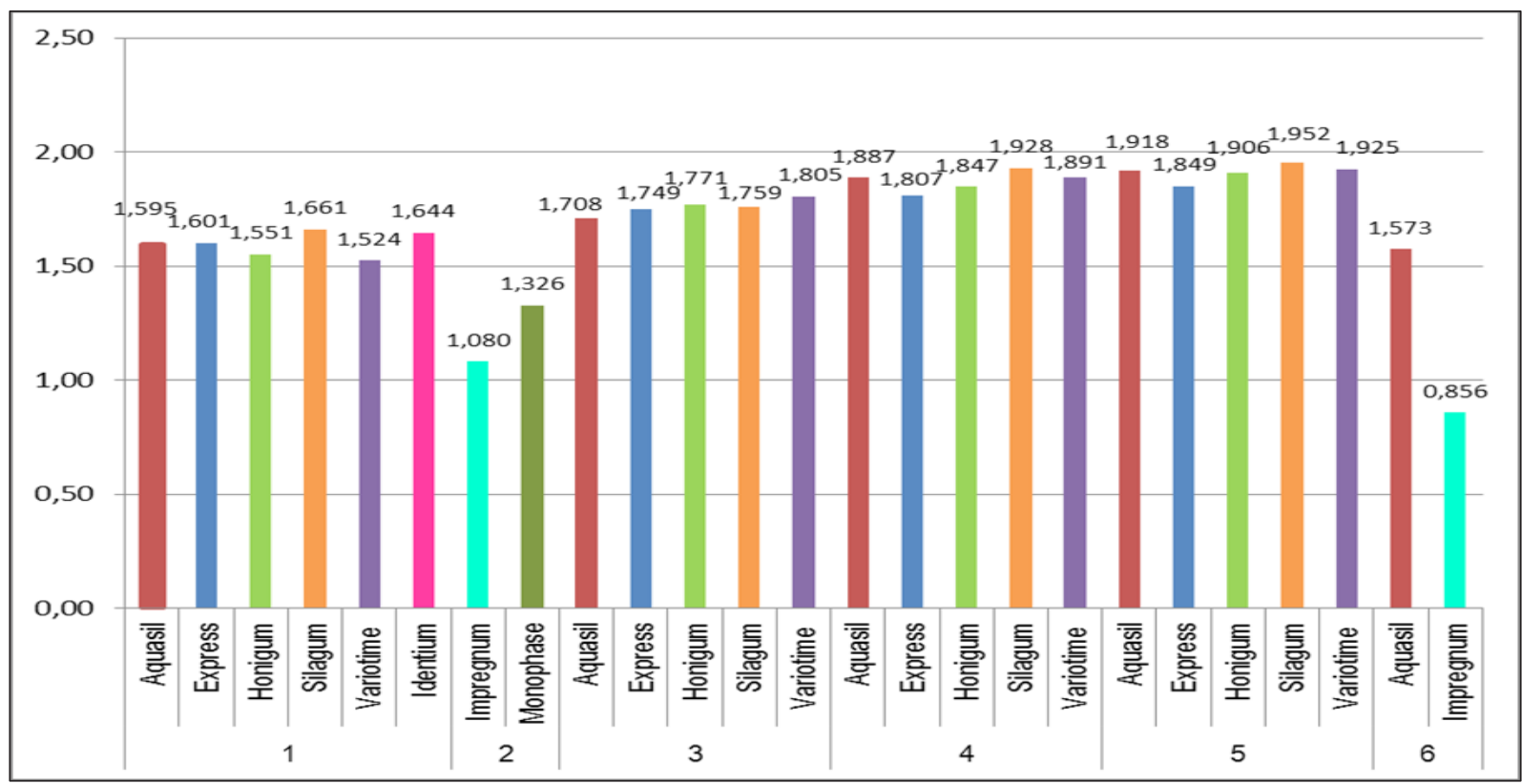

Fig. 5. Depth of flow of impression materials into the gingival sulcus using various impression techniques (mm). Legend:

1 -one-step two-phase technique.

2 - one-step one-phase technique.

3 - two-step two-phase mix technique with interdental spaces removed and gingival section excised.

4 -two-step two-phase technique using unprepared abutment teeth in the first impression layer.

5 -two-step two-phase technique with interdental spaces removed.

6 - one-step technique using individual tray.

$1.708 \mathrm{~mm}$ to $1.952 \mathrm{~mm}$ ). The deepest flow in the gingival pocket was achieved with Silagum in combination with the two-step two-phase technique. The material flow in the gingival sulcus was shallower when the gingival section in the first impression layer was removed (group 3; from $1.708 \mathrm{~mm}$ to $1.805 \mathrm{~mm}$ ).

Impression material flow with a medium consistency was weaker in the gingival sulcus $(1.08 \mathrm{~mm}$ and $1.326 \mathrm{~mm})$ when applying the one-step one-phase technique (2) compared with the one-step two-phase method (heavy and light body) (1, 3, 4, 5; from $1.524 \mathrm{~mm}$ up to $1.952 \mathrm{~mm}$ ). A comparison of the flow of different impression materials combined with different techniques showed statistically significant differences for most of the analysed materials $(p<0.001)$ with the exception of Impregum $(\mathrm{p}<0.05)$.

\section{Discussion}

Measurements of impression material penetration in the gingival sulcus revealed that two-step two-phase techniques combined with impression trays produced greater material flow in a $200 \mu \mathrm{m}$ gingival sulcus than did the one-step two-phase technique, irrespective of the material type. Material flow in the sulcus was considerably weaker with the one-step, one-phase technique. These differences turned out to be statistically significant.

The use of a custom-made tray impeded the ability of impression materials to flow into the gingival sulcus when compared with the singestep technique utilizing a standard tray. The first layer of a one-step two-phase heavy body impression pushes the light body into the sulcus, while insufficient pressure acts on the medium 
Ta b le 2. Comparison of average flow depths for different impression materials depending on the technique used

\begin{tabular}{|c|c|c|c|c|c|c|c|}
\hline \multirow{2}{*}{$\begin{array}{c}\text { Impression } \\
\text { material }\end{array}$} & \multirow{2}{*}{ Technique } & \multicolumn{6}{|c|}{ Calculated parameters } \\
\hline & & $\min$ & $\max$ & $\mathrm{x}$ & $\mathrm{Me}$ & SD & $\mathrm{v}(\%)$ \\
\hline \multirow{5}{*}{ Aquasil } & 1 & 1.45 & 1.74 & 1.595 & 1.615 & 0.090 & 5.7 \\
\hline & 3 & 1.58 & 1.84 & 1.708 & 1.690 & 0.090 & 5.3 \\
\hline & 4 & 1.74 & 2.08 & 1.887 & 1.870 & 0.113 & 6.0 \\
\hline & 5 & 1.72 & 2.10 & 1.918 & 1.930 & 0.102 & 5.3 \\
\hline & 6 & 1.44 & 1.78 & 1.573 & 1.545 & 0.100 & 6.4 \\
\hline \multicolumn{2}{|r|}{ Comparison } & \multicolumn{6}{|c|}{$\mathrm{F}=26.104 ; \mathrm{p}<0.001$} \\
\hline \multirow{4}{*}{ Express } & 1 & 1.49 & 1.70 & 1.601 & 1.615 & 0.062 & 3.9 \\
\hline & 3 & 1.62 & 1.86 & 1.749 & 1.755 & 0.084 & 4.8 \\
\hline & 4 & 1.72 & 1.89 & 1.807 & 1.810 & 0.059 & 3.3 \\
\hline & 5 & 1.78 & 1.97 & 1.849 & 1.835 & 0.061 & 3.3 \\
\hline \multicolumn{2}{|r|}{ Comparison } & \multicolumn{6}{|c|}{$\mathrm{F}=25.870 ; \mathrm{p}<0.001$} \\
\hline \multirow{4}{*}{ Honigum } & 1 & 1.47 & 1.63 & 1.551 & 1.560 & 0.057 & 3.7 \\
\hline & 3 & 1.68 & 1.86 & 1.771 & 1.790 & 0.064 & 3.6 \\
\hline & 4 & 1.68 & 2.07 & 1.847 & 1.835 & 0.123 & 6.7 \\
\hline & 5 & 1.80 & 1.98 & 1.906 & 1.915 & 0.053 & 2.8 \\
\hline \multicolumn{2}{|r|}{ Comparison } & \multicolumn{6}{|c|}{$\mathrm{F}=38.023 ; \mathrm{p}<0.001$} \\
\hline \multirow{4}{*}{ Silagum } & 1 & 1.55 & 1.75 & 1.661 & 1.645 & 0.061 & 3.7 \\
\hline & 3 & 1.67 & 1.87 & 1.759 & 1.750 & 0.068 & 3.9 \\
\hline & 4 & 1.74 & 2.08 & 1.928 & 1.980 & 0.123 & 6.4 \\
\hline & 5 & 1.76 & 2.10 & 1.952 & 1.995 & 0.125 & 6.4 \\
\hline \multicolumn{2}{|r|}{ Comparison } & \multicolumn{6}{|c|}{$\mathrm{F}=19.697 ; \mathrm{p}<0.001$} \\
\hline \multirow{4}{*}{ Variotime } & 1 & 1.40 & 1.65 & 1.524 & 1.535 & 0.085 & 5.6 \\
\hline & 3 & 1.74 & 1.89 & 1.805 & 1.815 & 0.054 & 3.0 \\
\hline & 4 & 1.77 & 2.04 & 1.891 & 1.885 & 0.086 & 4.6 \\
\hline & 5 & 1.83 & 2.10 & 1.925 & 1.920 & 0.076 & 3.9 \\
\hline \multicolumn{2}{|r|}{ Comparison } & \multicolumn{6}{|c|}{$\mathrm{F}=56.710 ; \mathrm{p}<0.001$} \\
\hline \multirow{2}{*}{ Impregum } & 2 & 0.90 & 1.22 & 1.080 & 1.055 & 0.13 & 10.5 \\
\hline & 6 & 0.44 & 1.19 & 0.856 & 0.900 & 0.233 & 27.3 \\
\hline \multicolumn{2}{|r|}{ Comparison } & \multicolumn{6}{|c|}{$\mathrm{z}=2.728 ; \mathrm{p}<0.05$} \\
\hline
\end{tabular}


materiak in the customized tray. An even more favourable effect is achieved with a heavy body material in a two-step two-phase impression, in which the first layer after polymerization acts as a press and pushes the light body into the gingival sulcus. Excision of the gingival section in the first layer of the material resulted in a slightly weaker flow of material into the gingival sulcus compared with the other two-step twophase methods tested. An impression taken with a basic impression material prepared in this way results in less of the light material being pushed into the gingival sulcus.

According to Finger et al., the two-step twophase method ensures better simulation of the narrow gingival sulci than the single-step twophase technique does. However, researchers found no differences between the impression techniques in a simulation of a $200 \mu \mathrm{m}$ gingival sulcus. Luthardt et al. ${ }^{9}$ compared the singlemix technique using Impregum with one-step two-phase and two-step two-phase methods combined with PVS Dimension Garant. They showed that the one-step two-phase method produced the most accurate simulation of the gingival section while the single-mix technique achieved worse results in this respect.

Takkahashi et al. ${ }^{12}$ studied the flow capabilities of Flexitime polyvinyl siloxane in gingival sulci. They used a material containing surfactants, as well as an equivalent medium without surface tension reducing agents. They compared the flow of the material into sulci with widths of $50 \mu \mathrm{m}, 100 \mu \mathrm{m}$ and $200 \mu \mathrm{m}$ within a temperature range of $23-37^{\circ} \mathrm{C}$. Although they found statistically significant relationships, they concluded that from a clinical point of view these are of little importance, and the factor that determines effective simulation is the correct opening of the gingival sulcus with a width of $200 \mu \mathrm{mS}$. Similar conclusions were reached by Baharav et al. ${ }^{13}$ in their study of 3 A-silicones (Examix, Elite, Express) and Permadyne. They used six metal standard models shaped like a prepared abutment tooth with a chamfer shoulder and grooves of varying width simulating a gingival sulcus $(100 \mu \mathrm{m}$ $400 \mu \mathrm{m})$. They did not show any significant variation between the different materials. Nevertheless, a relationship was clearly visible between the width of the sulcus and the accuracy of the simulated gingival part of the cast models. Simulation models with a 100 $\mu \mathrm{m}$ sulcus were characterized by significant distortion. Researchers report that the gingival sulcus should be open to a width of at least $150 \mu \mathrm{m}$ - in such conditions the model in the gingival section is the least deformed in relation to the standard. The only differences between the materials used in the study were observed in the case of Express, the models of which exhibited greater distortion than was the case with other materials.

Schaefera et al. ${ }^{14}$ made impressions of a single metal tooth using Identium, Panasil (VPS) and Impregum. The plaster models of an individual tooth were scanned, and then the resulting image was applied to the scan of the standard. As it turned out, the best material for simulating the gingival section was A-type silicone, followed by polyvinylsiloxane ether. The worst material in this respect was polyether. Scientists point to the excellent flow properties of liquid consistency VPS in the zone during subgingival preparation. Aimjirakul et al. ${ }^{15}$ demonstrated opposite results. They reported that polyether materials exhibit better penetration in $100 \mu \mathrm{m}$ and $200 \mu \mathrm{m}$ pockets than polyvinyl siloxane materials.

In light of the above, the best impression technique for prosthetic restorations involving subgingival preparation of abutment teeth would be a two-step two-phase method using unprepared abutment teeth in the first impression layer or a two-step, two-phase method with interdental spaces removed. The first layer of the material should not be removed from the gingival section. 


\section{Conclusions}

1. The greatest flow in the gingival sulcus was achieved with Silagum and the two-step two-phase technique

2. The flow of impression material in the gingival sulcus was greater with two-step two-phase techniques than with one-step one-phase methods.

3. Two-phase impressions in standard trays provide more accurate gingival impressions than one-step impressions taken with customized trays.

\section{References}

1. Mitchell Ch, Pintado $M$, Douglas $W$ : Nondestructive, in vitro quantification of crown margins. J Prosthet Dent 2001; 85: 575-584.

2. Dejak B: Kompendium wykonywania uzupełnień protetycznych. Med Tour Press International 2014; 65-85.

3. Majewski S: Współczesna protetyka stomatologiczna. Edra Urban\&Partner 2014; 192.

4. Perakis $N$, Belser $U$, Magne P: Final impressions: a review of material properties and de-scription of a current technique. Int $\mathrm{J}$ Periodontics Restorative Dent 2004; 24: 109117.

5. Wöstmanna B, Rehmanna $P$, Trost $D$, Balkenhol M: Effect of different retraction and impres-sion techniques on the marginal fit of crowns. J Prosthet Dent 2008; 36: 508512.

6. Jokstad A: Clinical trial of gingival retraction cords. J Prosthet Dent 1999; 81: 258-261.

7. Gupta A, Prithviraj D, Gupta D, Shruti D: Clinical evaluation of three new gingival retraction systems: A research report. J Indian Prosthodont Soc 2013; 13: 36-42.
8. Górska R, Konopka T: Periodontologia współczesna. Med Tour Pres International 2013; 89.

9. Luthardt $R$, Walter $M$, Weber A, Koch $R$, Rudolph H: Clinical parameters influencing the accuracy of 1- and 2-stage impressions: A randomized controlled trial. Int J Prosthodont 2008; 21: 322-327.

10. Felton D, Kanoy B, Bayne S, Wirthman G: Effect of in vivo crown margin discrepancies on periodontal health. J Prosthet Dent 1991; 65: 357-364.

11. Naveen $Y G$, Patil R: Effect of the Impression Margin Thickness on the Linear Accuracy of Impression and Stone Dies: An In Vitro Study. J Indian Prosthodont Soc 2013; 13: 13-18.

12. Takahashi H, Finger W, Kurokawa R, Furukawa M, Komatsu M: Sulcus depth reproduction with polyvinyl siloxane impression material: Effects of hydrophilicity and impression temperature, Quintessence Int 2010; 41: 43-50.

13. Baharav H, Kupershmidt I, Laufer B, Cardash H: The effect of sulcular width on the linear accuracy of impression materials in the presence of an undercut. Int J Prosthodont 2004; 17: 585-589.

14. Schaefer O, Schmidt M, Goebel R, Kuepper H: Qualitative and quantitative threedimensional accuracy of a single tooth captured by elastomeric impression materials: An in vitro study. J Prosthet Dent 2012; 108: 165-172.

15. Aimjirakul P, Masuda T, Takahashi H, Miura $H$ : Gingival sulcus simulation model for evaluating the penetration characteristics of elastomeric impression materials. Int $\mathrm{J}$ Prosthodont 2003; 16: 385-389.

Zaakceptowano do druku: 06.04.2020 r.

Adres autorów: 92-213 Łódź, ul. Pomorska 251.

(C) Zarząd Główny PTS 2020. 